\title{
We Have Always Had Mashups, or Mashing Up Transmediality
}

\section{George P. Landow}

Brown University, USA

doi: 10.7358/ijtl-2015-001-land

george@landow.com

\begin{abstract}
After examining the intertwined concepts of media, information technology, and mashups, this essay draws upon examples from ancient Greek literature based upon orality, Latin scribal culture, and printed poetry to demonstrate that the practice of mash-up is central to our understanding of both media and transmediality. Translating texts originally created in another language and verse form exemplifies one major instance of transmediality, and the way Elizabethan English poets self-consciously borrow, rewrite, and challenge Catullus provide far more wonderfully outrageous examples of mash-up than modern musical ones.
\end{abstract}

Keywords: mashup; medium; transmediality; literary tradition; transliterality; Catullus; poems.

The term mashup originally comes from British-West Indies slang meaning to be intoxicated, or as a description for something or someone not functioning as intended. In recent English parlance it can refer to music, where people seamlessly combine audio from one song with the vocal track from another-thereby mashing them together to create something new. - Wikipedia

\section{Mashup, MEdium, AND 'TRANSmedia' Literacy}

According to Wikipedia, that wonderful example of text-and-image mashups in a digital, networked environment, a mashup - or mash up or mash-up - "is a song or composition created by blending two or more pre-recorded songs, usually by overlaying the vocal track of one song seamlessly over the instru- 
mental track of another." According to the Wikipedia article, which contains a useful list of examples, "The original manifestation of mashups in the 2000s was putting an a cappella against a completely different backing track, in order to make a "third song". Following "A Stroke of Genie-us" in 2001, the genre has continued to focus on this basic premise." As I hope to show, mashups have been around a lot longer than $2001^{1}$. As should be obvious by now "my" text is already a mashup, a textual collage, as is any text that includes quotations from another, since texts inevitably come into being as collages, mashups, of other texts, particularly when they include material, such as illustrations, graphs, or diagrams, in another medium.

To understand the fundamental connections between text, image, mashup, and transmedia literacy, let us look at what we mean by medium. Perhaps the best place to begin is to emphasize that a medium is always something in the middle, which implies, as Derrida so often emphasized, we always have something between us and the experience, the perception, the thought, the... whatever. Thus, according to various online dictionaries, a medium is "an intervening substance through which something else is transmitted or carried on" or "an agency by which something is accomplished, conveyed, or transferred, as in "the train was the usual medium of transportation in those days." It is also a "surrounding environment in which something functions and thrives." This idea that a medium is something between us and something else also appears in another dictionary definition: a medium is also "a specific kind of artistic technique or means of expression as determined by the materials used or the creative methods involved, and it can also mean a specific artistic technique: oils as a medium."

The multiple meanings of medium complicate the ideas of the transmedia text and the literacy required to understand it. To make things a bit clearer, let us look at the various kinds of mediums found in Orb's "Little Fluffy Clouds," techno music whose samplings and remixing inevitably complicates our conception of what constitutes a medium and transmedia literacy. Version no. 2 of "Little Fluffy Clouds" - there are at least seven ${ }^{2}$ - begins with the sound

1 Another Wikipedia article that defines a mashup in WWW terms as "a web page, or web application, that uses content from more than one source to create a single new service displayed in a single graphical interface. For example, you could combine the addresses and photographs of your library branches with a Google map to create a map mashup." The article continues, pointing out that the term "implies easy, fast integration, frequently using open application programming interfaces (open API) and data sources to produce enriched results that were not necessarily the original reason for producing the raw source data."

2 Orb 1991a has five versions of the title song, and the one I am discussing runs 2 minutes and 58 seconds. Another versions appears on Orb 1991b and Orb 1993 contains a version recorded in Tokyo that is 10 minutes and 55 seconds.

International Journal of Transmedia Literacy - 1.1 - December 2015

http://www.ledonline.it/transmedialiteracy/ 
of something falling into water and making a loud splash, after which, seven seconds in, a young man's voice asks, "What were the clouds like when you were young?" After a taking loud intake of air a young woman with a pleasant breathy voice replies,

They ran on forever, they... when... we lived in Arizona. and the skies always had little fluffy clouds in 'em, and... uhhm they were long and clear and there were lots of stars at night, and uhh when it would rain it would all turn it they were beautiful, the most beautiful skies as a matter if fact ahh the sunsets were... purple and red and yellow and on fire 'nn the clouds would catch the colors everywhere. It was unique. I used to look at them all the time when I was little. You don't see that... ahhh. ${ }^{3}$

A drum beat appears around "they were long and clear," and later the beat slows, at which point a different male voice than that of the initial questioner says rather bathetically, "Those were the days" (irony? sarcasm? inept attempt at seriousness?) At various words the beat speeds up and becomes louder, and after the first run through of the girl's words and interspersed sounds we hear a pause followed by repeated intakes of breath which gradually speeds up as we hear a bell tolling once, and then the words appear in fragments, as "ah-ah-ah" and then are repeated, one of the most obvious and aggressive forms being the repeated first syllable of "little," which appears as something like "lihlihlihlih." These sounds come interspersed with phrases from the first speech and other sounds.

So what's the medium here, or rather what mediums do we encounter here? Using one of the most common meanings of the term, we would say that the storage device on which "Little Fluffy Clouds" resides is a medium - in my case either the CD-ROM (not yet a DVD!) on which I first heard the cut I'm discussing or the computer memory in which it remains in the form of computer code on my laptop and also on a backup memory stick. But note: as we listen we hear the (recording of) the young woman's voice sampled and divided into shorter and shorter passages, some of them simply her intake of breath between words, it becomes obvious that her voice itself functions as a medium as do the sentences she has spoken and the individual syllables. Orb takes these sound fragments and, like a popularized John Cage, turns them into music, in this case by adding a rhythmic beat and other sampled sounds and speech. To put this another way, each of these elements functions as both information technology and medium.

Information technology of course does not begin with computers, the first infotech probably taking the form of grunts and other uttered sounds

3 In this slightly incomplete transcription of the beginning of this version of "Little Fluffy Clouds" my ellipses indicate the speaker's pauses rather than omitted words or sounds. 
whether combined or not with gestures. Spoken syntactic language is the first great information technology, and chronologically it is followed by ideographic and syllabic writing, printing, printing with moveable type, high-speed printing, telegraphy, photography, cinema, all the way up to networked digital information technology (Landow 2006, 29-33). Here a fundamental change or shift takes place because, for the first time, writing changes from physical marks on physical surfaces to computer code, which allows particular kinds of virtuality, reproducibility, speed of transmission, and so on. As we consider the nature of medium and information technology, we also realize that specific literary forms or genres themselves function as subcategories of both information technology and medium. The invocation of the muse in epic poetry, like stream-of-conscious narration in Joyce and Woolf, is not simply a literary technique but itself a form of technology, and, like the chopped, processed, atomized voice in "Little Fluffy Clouds," it offers examples of mashup and transmedia literacy.

\section{TRANSMEDIALITY, MASHUPS, AND LITERARY TRADITION}

Now let's turn to text that during the past two millennia has generated a good deal of fan fiction - The Iliad - and let's begin by looking at the invocations of the muses that open two very different English translations (which are, as we shall see, themselves mashups). First, Samuel Butler's Victorian prose translation:

Sing, $\mathrm{O}$ goddess, the anger of Achilles son of Peleus, that brought countless ills upon the Achaeans. Many a brave soul did it send hurrying down to Hades, and many a hero did it yield a prey to dogs and vultures, for so were the counsels of Jove fulfilled from the day on which the son of Atreus, king of men, and great Achilles, first fell out with one another. ${ }^{4}$

Compare this passage to Alexander Pope's translation into neoclassic couplets, into, that is, a verse form emphasizing (and therefore sometimes necessarily creating and imposing parallels and contrasts not in the original):

Achilles' wrath, to Greece the direful spring

Of woes unnumber'd, heavenly goddess, sing!

That wrath which hurl'd to Pluto's gloomy reign

The souls of mighty chiefs untimely slain;

Whose limbs unburied on the naked shore,

${ }^{4}$ Unless otherwise noted I have taken these translations from those available at Project Gutenberg. 
Devouring dogs and hungry vultures tore.

Since great Achilles and Atrides strove,

Such was the sovereign doom, and such the will of Jove!

Declare, O Muse! in what ill-fated hour

Sprung the fierce strife, from what offended power

Latona's son a dire contagion spread,

And heap'd the camp with mountains of the dead

These two examples of translations that, like all translations, inevitably betray the classical Greek original, we see how they function as mashups in multiple ways. First of all, both Butler's Victorian prose translation and Pope's Augustan poetic one exemplify collisions of the English language with ancient Greek. But the Greek text, is itself a mashup as well as a fictionalization of older oral performances that were partly extemporized and therefore always varied. (I am here for the sake of argument assuming that Homer's oral performances had a single "original," and I am also setting aside the question whether there actually ever was one "Homer" at all). In addition to the transmedia mashups of orality and literacy and those of ancient Greek and modern English there is also the matter of radically different poetic metrics. Such collisions of vastly different ages of technology and media, I suggest, represent far more outrageous mashups that imposing upon each other Taylor Swift and the Jackson Five, as Chamberland has done, or forcing Beastie Boys and Spice Girls into the same musical sound space as Daw Gun Double Shot has done in "If you Wannabe my Ladies 5." Butler's translation, like Pope's, exemplifies one form transmedia literacy. Now look what happens when Vergil comes along:

ARMA virumque cano, Troiae qui primus ab oris
Italiam, fato profugus, Laviniaque venit
litora, multum ille et terris iactatus et alto
vi superum saevae memorem Iunonis ob iram;
multa quoque et bello passus, dum conderet urbem,
inferretque deos Latio, genus unde Latinum,
Albanique patres, atque altae moenia Romae.
Musa, mibi causas memora, quo numine laeso,
quidve dolens, regina deum tot volvere casus
insignem pietate virum, tot adire labors
impulerit. Tantaene animis caelestibus irae?

And here is an English translation:

5 Googling "Mashup" will produce lists of sites with such musical and video mashups, many of which offer classifications according to mode. 
Arms, and the man I sing, who, forc'd by fate,

And haughty Juno's unrelenting hate,

Expell'd and exil'd, left the Trojan shore.

Long labors, both by sea and land, he bore,

And in the doubtful war,before he won

The Latian realm, and built the destin'd town;

His banish'd gods restor'd to rites divine,

And settled sure succession in his line,

From whence the race of Alban fathers come,

And the long glories of majestic Rome'

O Muse! the causes and the crimes relate;

What goddess was provok'd, and whence her hate;

For what offense the Queen of Heav'n began

To persecute so brave, so just a man;

Involv'd his anxious life in endless cares,

Expos'd to wants, and hurried into wars!

Can heav'nly minds such high resentment show,

Or exercise their spite in human woe? ${ }^{6}$

In addition to all the different forms of mashups that occur in English prose and poetic translations of The Iliad, others appear when when Vergil challenges and rewrites the Greek written texts he encountered. Homer's epic similes famously compare the acts of its heroes to subjects familiar to a pastoral and agricultural culture, comparing Ajax's stubborn resistance to attack to a donkey unwilling to be pulled from a field. Vergil, however, sings the epic of a city state, and his epic similes draw upon urban life and juridical law.

Similar collisions and mashups occur in John Milton's Christian epic "Paradise Lost":

Of man's first disobedience, and the fruit

Of that forbidden tree, whose mortal taste

Brought death into the world, and all our woe,

With loss of Eden, till one greater man

Restore us, and regain the blissful Seat,

Sing heavenly Muse, that on the secret top

Of Oreb, or of Sinai, didst inspire

That shepherd, who first taught the chosen Seed,

In the beginning how the heavens and earth

Rose out of chaos: Or if Sion Hill

Delight thee more, and Siloa's brook that flowed

6 Project Gutenberg, as far as I can tell, provides no information about the translation or source of the text.

International Journal of Transmedia Literacy - 1.1 - December 2015

http://www.ledonline.it/transmedialiteracy/ 
Fast by the oracle of God; I thence

Invoke thy aid to my adventurous song, That with no middle flight intends to soar

Above the Aonian Mount, while it pursues

Things unattempted yet in Prose or Rhyme.

And chiefly Thou O Spirit, that dost prefer

Before all Temples the upright heart and pure,

Instruct me, for thou know'st; thou from the first

Wast present, and with mighty wings outspread

Dove-like sat'st brooding on the vast abyss

And madest it pregnant: what in me is dark

Illumine, what is low raise and support;

That to the highth of this great Argument

I may assert eternal providence,

And justify the ways of God to men. (Milton 1968, 458-462)

Once again we encounter an expert in transmedia literacy committing an act of literary, cultural, and religious aggression... and thereby producing major poetry. Paradise Lost is a text disseminated and read in print, whereas Vergil's text, though written, represents a hybrid form of transmediaity, since although modern readers almost alway read it silently, when it was written and for much of its history Vergil's Aeneid (unlike its modern translations) was read aloud and possibly chanted. To be read correctly, I propose, The Aeneid, like The Iliad, has to be read with a kind of double awareness, one that sees its existence in two modes or two mediums, the oral and the written. It was therefore literally a transmedia art form that created a bridge between orality and literacy, a hybrid that tried and long succeeded holding together two different media and two very different media cultures. Second, "Paradise Lost" is a self-consciously Christian text written in part as a proof-of-concept text, that is, to show that since he believes Christianity is the highest and best and truest religion it must also have the finest poetry, so he must create an epic that challenges and surpasses all Pagan ones, and, moreover, since Milton is a seventeenth-century Puritan highly antagonistic to the Church of Rome, his version of the epic, the best epic, not only has to mashup the best Roman Catholic epic - Dante's Divina Commedia - it has to surpass it. So where do we see signs of Miltonic mashup? Take the first line, which announces Milton's epic subject, which turns out to be not the anger of some pagan brute nor the sorrows and triumphs of pagan who (supposedly) founded Rome but the central narrative for him - the "Fall of Man". Note, too, what has happened to Homer's goddess and Vergil's muse: they have metamorphosed into the "heavenly muse" that came to Moses "on the secret top of Oreb, or of Sinai," when it served to communicate divine truth in the form of the moral law, the 
ten commandments. But since Milton is a Christian who takes Moses - "That Shepherd, who first taught the chosen Seed" - as a divinely intended prefiguration (or type) of Christ, his muse doubles becoming/revealing itself to be the Holy Spirit that was from the beginning of creation "present, and with mighty wings outspread / Dove-like satst brooding on the vast Abyss /And mad'st it pregnant ${ }^{7} . "$

\section{ROMANTIC CONCEPTIONS OF CREATIVITY AND RESISTANCE TO MASHUPS AND TRANSLITERALITY}

The question then arises, if the mashup and transmedia literacy constitutes such an important role in European literary history, why haven't we noticed it more. The answer in brief: mashups, with their appropriations and revisions, do not the fit the fundamentally romantic theories of art and literature, which emphasize originality and individuality, that still pervade much of our literature and scholarship. M.H. Abrams's enormously influential The Mirror and the Lamp (1953) provides a valuable way into discussing fan fiction and mashups and resistance to the first and explaining blindness to the second (Abrams 1953). Much of our attitude toward such active reading and listening derives from our essentially Romantic assumptions about composition and so-called creativity. Abrams begins his argument by pointing out that the once nearuniversal tendency to discuss art in terms of author and artist arrived on the scene quite late in the 2500 year-old history of Western aesthetics and critical theory. As Abrams points out, to pose and answer aesthetic questions in terms of the relation of art to the artist - or text, image, and sound to author - rather than to external nature, or to the audience, or to the internal requirements of the work itself, was the characteristic tendency of modern criticism up to a few decades ago, and it continued to be the propensity of a great many - perhaps the majority - of critics today. This point of view is very young when measured against the twenty-five-hundred-year history of Western theory of art, for its emergence as a comprehensive approach to art shared by a large number of critics, dates back not much more than a century and a half.

Abrams explains that all discussions of them discuss four elements - text or work, author, reality or nature, and audience - but define themselves by which one of the four they emphasize. First, there is the work, the artistic product itself. And since this is a human product, an artifact, the second common element is the artificer, the artist. Third, the work is taken to have a subject which, directly

7 For discussions of typological symbolism in readings of Milton, see Lewalski 1985. 
or indirectly, is derived from existing things - to be about, or signify, or reflect something which either is, or bears some relation to, an objective state of affairs. This third element, whether held to consist of people and actions, ideas and feelings, material things and events, or super-sensible essences, has frequently been denoted by that-word-of-all-work, "nature;" but let us use the more neutral and comprehensive term, universe, instead. For the final element we have the audience: the listeners, spectators, or readers to whom the work is addressed, or to whom, at any rate, it becomes available.

The classical or mimetic theory found in Plato and classical theorists considers text (or the work of art) chiefly in relation to Nature or the universe, so it proceeds on the assumption that the fundamental principle of art is imitation. It therefore downplays the role of artist, who at best should function as a transparent lens. Its basic criterion is accuracy, its associated information technologies are oral and scribal. In contrast, pragmatic, rhetorical, or Renaissance theory, such as we find from Aristotle to Sir Philip Sidney, considers the work chiefly relation to the audience, thus making rhetoric or the arts of persuasion its fundamental mode and its criterion of success producing an intended effect, such pity and fear in tragedy and laughter in comedy. Artists and writers have to be effective not sincere. Here one imitates only in order to convince, entertains only in order to teach. Explicitly taking literature and the other arts as pragmatic techné, pragmatic theory develops the literary technologies known as genres and genre-specific techniques. Twentieth-century reader-response theory, such as that espoused by Wolfgang Iser and Stanley Fish, is the interpretive sibling of conceptions of art and artist found in the Reniassance and Augustan age. In sharp contrast, romantic or expressive theory, which considers the work primarily in relation to the the artist or poet, emphasizes that they have an experience to which they react and in the next step express it - think Wordsworth's description of poetry as emotion recollected in tranquility - and with this concentration on the author comes new criteria: sincerity, intensity, originality, and creativity. With originality comes alienation and the need for critics to explain art and literature, which will supposedly always be far in advance of audience understanding. Associated with print culture, first simple hand-set type and later high-speed printing, this attitude towards creativity produces mass audiences and new ideas of intellectual property.

Objective or postmodern theories of artistic production, concentrate upon the relatin of the text to itself, emphasizes intertextuality rather than influence and an assemblage, collage, and mash-up, such as we find in digital information technology and its immediate predecessors.

One recent author, tongue in cheek, who sums up the notion of literature as technology in ways that mock the attitudes so resistant to mashups and transmedia literacy is Jasper Fforde, who has great fun explaining an anti- 
romantic explanation of the relation of information technology and narrative. In The Well of Lost Plots and his other novels set in an alternative universe in which fictional characters and real people move between this real world and the world of fiction, Jasper Fforde creates comedy from many ideas accepted by both eighteenth-century Neoclassical and twentieth-century Poststructuralist literary theorists - not as one might expect by mocking these ideas but by dramatizing them, by making them the stuff of his plots. In particular, Fforde, like any good neoclassicist, rejects romantic and modernist notions of creativity and originality: according to him, literature, especially storytelling, is a technology employing lots of off-the-shelf parts. As Miss Havisham (a very different character than the one finds in Dickens's Great Expectations) explains, all characters begin as generic types that authors then modify and embellish as they wish. Plots, too, have a limited number of possibilities, and this turns out to threatens literature as we know it. Most important media and infotech should be thought of as technologies, for as Wordmaster (Xavier Libris) explains, Story Operating Systems,

First there was OralTrad, upgraded ten thousand years later by the rhyming (for easier recall) OralTradPlus. For thousands of years this was the only Story Operating System and it is still in use today. The system branched in two about twenty thousand years ago; on one side with CaveDaub Pro (forerunner of Paint Plus V2.3, GrecianUrn VI.2, Sculpt- Marble VI.4 and the latest, all-encompassing Super Artistic Expression-5). The other strand, the Picto-Phonetic Storytelling Systems, started with ClayTablet V2.1 and went through several competing systems (Wax-Tablet, Papyrus, VellumPlus) before merging into the award-winning SCROLL, which was upgraded eight times to V3.5 before being swept aside by the all new and clearly superior BOOK VI. Stable, easy to store and transport, compact and with a workable index, BOOK has led the way for nearly eighteen hundred years. (Ford 2003)

\section{Mashups, Catullus, and Poems written about other Poems}

Certainly, modern sound recording technologies made mashups a popular, prominent part of recent culture, but Cubist collage and fan fiction that goes back at least to the days of the mimeograph remind us that reproducibility has always encouraged it. And when two media ecologies, such as orality and scribal cultures, come together mashups become a dominant, though not always recognized form.

From the mashups of The Iliad and The Aeneid to reconceptions of StarTrek and Buffy, Fan fiction in its many forms has been central to major literary traditions in the West. I would ague that the technique and mindset of the mashup is central to the writer's very notion of a literary tradition. Take, for 
example, a single poem by Catullus in which the speaker tries to argue the object of desire into his bed, and let us observe how it has generated a chain of mashups in English poetry. First Catullus:

Vivamus, mea Lesbia, atque amemus,

Rumoresque senum severiorum

Omnes unius aestimemus assis.

Soles occidere et redire possunt:

Nobis cum semel occidit brevis lux,

Nox est perpetua una dormienda.

Da mi basia mille, deinde centum,

Dein mille altera, dein secunda centum,

Deinde usque altera mille, deinde centum.

Dein, cum milia multa fecerimus,

Conturbabimus illa, ne sciamus,

Aut nequis malus invidere possit,

Cum tantum sciet esse basiorum.

Now a version by Robinson Ellis:

Living, Lesbia, we should e'en be loving.

Sour severity, tongue of eld maligning,

All be to us a penny's estimation.

Suns set only to rise again to-morrow.

We, when sets in a little hour the brief light,

Sleep one infinite age, a night for ever.

Thousand kisses, anon to these an hundred,

Thousand kisses again, another hundred,

Thousand give me again, another hundred.

Then once heedfully counted all the thousands,

We'll uncount them as idly; so we shall not

Know, nor traitorous eye shall envy, knowing

All those myriad happy many kisses.

Another by Richard Burton, translator of the Kama Sutra, the Perfumed Garden, who refused (to his wife's annoyance) to excise the bawdier parts of the Thousand and One Nights:

Love we (my Lesbia!) and live we our day,

While all stern sayings crabbed sages say,

At one doit's value let us price and prize!

International Journal of Transmedia Literacy - 1.1 - December 2015

http://www.ledonline.it/transmedialiteracy/ 
The Suns can westward sink again to rise

But we, extinguished once our tiny light,

Perforce shall slumber through one lasting night!

Kiss me a thousand times, then hundred more,

Then thousand others, then a new five-score,

Still other thousand other hundred store.

Last when the sums to many thousands grow,

The tale let's trouble till no more we know,

Nor envious wight despiteful shall misween us

Knowing how many kisses have been kissed between us.

Frank O. Copley, a twentieth-century translator, has a modernist take on the middle portion of the poem:

the Sun dies every night

in the morning he's there again

you and I, now,

when our brief tiny flicks out,

it's night for us, one single

everlasting

Night. (Catullus 1957)

But let's put Catullus into the guise of the pastoral - a mashup of genres and forms - and pastoral, mind you, as seen by someone writing in Elizabethan England when the English transmutation of the Italian sonnet of Dante and Petrarch has just taken form. Nicolas Poussin might have argued in his famous paintings of Arcadian shepherds deciphering the inscription on a tomb, "Et in Arcaia ego" - There is death even in an idealized pastoral world - Christopher Marlowe and some of those who follow leave out death and carpe diem argument: First we have Christopher Marlowe's "The Passionate Shepherd to His Love”:

COME live with me and be my love,

And we will all the pleasures prove

That valleys, groves, hills, and fields,

Woods or steepy mountain yields.

And we will sit upon the rocks,

Seeing the shepherds feed their flocks,

By shallow rivers to whose falls

Melodious birds sing madrigals.

And I will make thee beds of roses

And a thousand fragrant posies,

A cap of flowers, and a kirtle 
Embroidered all with leaves of myrtle;

A gown made of the finest wool

Which from our pretty lambs we pull;

Fair lined slippers for the cold,

With buckles of th purest gold;

A belt of straw and ivy buds,

With coral clasps and amber studs:

And if these pleasures may thee move,

Come live with me and be my love.

The shepherds' swains shall dance and sing

For thy delight each May morning:

If these delights thy mind may move,

Then live with me and be my love.

John Donne, who encrusts the pastoral with artifice in "The Bait," gives it another twist, enticing the desired one with "some new pleasures." Her are the first two of seven stanzas:

Come live with me and be my love.

And we will some new pleasures prove

Of golden sands and cristall brookes,

With silken lines and silver hookes.

There will the river whispering run

Warmed by thy eyes, more than the Sunne.

And there th'inamoure'd fish will stay,

Begging themselves they may betray. (Donne 1965, 32)

Shakespeare takes a turn, emphasizing not the new pleasures but, like Catullus, that the time of eternal night is soon upon us and there will be no more pleasures:

What's to come is still unsure:

In delay there lies no plenty;

Then come kiss me, sweet and twenty

Youth's a stuff will not endure.

["O Mistress Mine, Where Are You Roaming?"]

Ben Jonson's “Song to Celia” returns closer to the Latin source:

Come, my CELIA, let us prove,

While we may, the sports of love;

Time will not be ours for ever:

He at length our good will sever. 
Spend not then his gifts in vain.

Suns that set, may rise again:

But if once we lose this light,

'Tis with us perpetual night.

Why should we defer our joys?

Fame and rumor are but toys.

Cannot we delude the eyes

Of a few poor household spies;

Or his easier ears beguile,

So removed by our wile?

'Tis no sin love's fruit to steal,

But the sweet theft to reveal:

To be taken, to be seen,

These have crimes accounted been.

Most elaborate and most brilliant of all seventeenth-century Catullean mashups is Andrew Marvell's “To His Coy Mistress," which prepares for the arrival of death with pretended willingnness to defer pleasure:

Had we but world enough and time,

This coyness, lady, were no crime.

We would sit down and think which way

To walk, and pass our long love's day.

Thou by the Indian Ganges' side

Should'st rubies find: I by the tide

Of Humber would complain. I would

Love you ten years before the Flood,

And you should, if you please, refuse

Till the conversion of the Jews.

My vegetable love should grow

Vaster than empires and more slow.

An hundred years should go to praise

Thine eyes, and on thy forehead gaze;

Two hundred to adore each breast,

But thirty thousand to the rest.

And then comes the turn, as he again expands upon the Catullian argument:

But at my back I always hear

Time's winged chariot hurrying near,

And yonder all before us lie

Deserts of vast eternity.

Thy beauty shall no more be found, 
Nor in thy marble vault shall sound

My echoing song; then worms shall try

That long-preserved virginity,

And your quaint honour turn to dust,

And into ashes all my lust.

The grave's a fine and private place,

But none, I think, do there embrace.

But as they adverts exclaim on late-night American television and third-rate channels, "Wait there's more!" One this kind of mashup has entered the popular imagination (in this case the educated nineteenth-century British reader), one can crunch genres and meanings even more wildly, as in this Victorian political cartoon that appeared in Punch: (Figure 1)

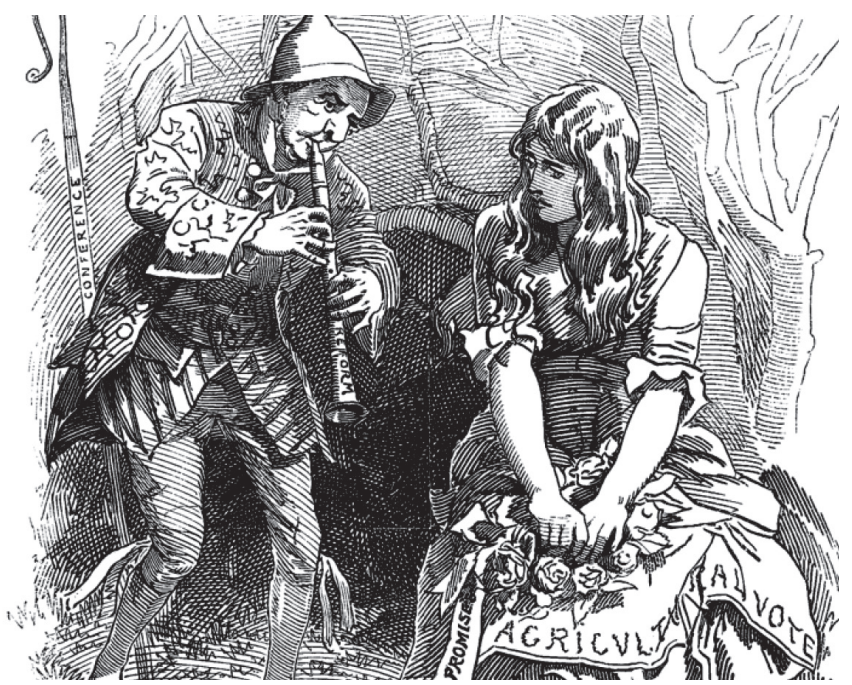

Figure 1

Illustration from "The Passionate Shepherd to his Love",

in Punch, or the London Charivari, Volume 101, December 19, 1891.

The first of the two parodic poems that accompany the cartoon begins:

"COME LIVE WITH ME, AND BE MY LOVE

AND WE WILL ALL THE PLEASURES PROVE

THAT LAND REFORM, ALLOTTED FIELD,

AND VILLAGE COUNCILS SOON MUST YIELD."

And thou shalt sit at ease, and mock

The Tory Shepherds of the flock, 
The nymph's response is based on one by Sir Walter Raleigh:

If I were sure 'twere sooth thou'st sung, That truth were on thy silvery tongue; These pleasures must my passion move To live with thee and be thy love...

But promises so oft are rotten;

I've oft been wooed, and oft forgotten!

Free vote, fair rating, open school,

Good wage, intelligent self-rule,

These are enticements me would move

To live with thee and be thy love.

The transmediality of this group of involves multiple concatenations of word and image - not only the identifying texts in the cartoon that insures the reader will grasp the satiric point but also the relation of each parodic poem to the image and of course to the chain of poems written as much about other poems as about their ostensible subject.

Late on evening while reading through a recently published anthology of Greek poetry that I had received as a present, I came upon the translation by Rachel Hadas of the following poem by Asclepiades (c.300 BC) that made me realize perhaps even Catullus $\mathrm{V}$ might be a mash-up, for perhaps this all goes back to

Girl, why so miserly with your virginity?

None will make love to you

in Hades down below.

Aprodite's joys

are for girls and boys.

We all as ash and bone lie down in Acheron. 


\section{REFERENCES}

Abrams, Mike H. 1953. The Mirror and the Lamp: Romantic Theory and the Critical Tradition. New York: Oxford University Press.

Catullus, Gaius Valerius. 1957. The Complete Poetry. Translated by Frank O. Copley. Ann Arbor: University of Michigan Press.

Ford, Jasper. 2003. The Well of Lost Plots. London: Penguin.

Donne, John. 1965. The Elegies and the Songs and Sonnets. Edited by Helen Gardner. Oxford: Clarendon Press.

Landow, George P. 2006. Hypertext 3.0: Critical Theory and New Media in an Era of Globalization. Baltimore: Johns Hopkins University Press.

Lewalski, Barbara. 1985. Paradise lost and the rhetoric of literary forms. Princeton: Princeton University Press.

Milton, John. 1968. Paradise Lost. Edited by John Carey and Alastair Fowler. London: Longman.

Orb. 1991a. Little Fluffy Clouds. New York: Big Life/Mercury/Polygram.

Orb. 1991b. Adventures beyong the ultraworld. New York Island Red Records.

Orb. 1993. Live 93. New York: Island Records. 